\title{
The Effect of Lameness on Milk Yield in Dairy Cows
}

\author{
O. KOCAK, B. EKIZ \\ Istanbul University, Faculty of Veterinary Medicine, Department of Animal Breeding and Husbandry, \\ Istanbul, Turkey \\ Received January 25, 2005 \\ Accepted March 16, 2006
}

\begin{abstract}
Kocak O., B. Ekiz: The Effect of Lameness on Milk Yield in Dairy Cows. Acta Vet. Brno 2006, 75: 79-84

This study was conducted to investigate the incidence of lameness in a private dairy herd and the effect of lameness on the weekly milk yields and lactation milk yield of dairy cows. Data used in the analyses comprised 953 lactation data from 787 Holstein cows. The traits analysed were daily averages of weekly milk yield and lactation milk yield. To determine the effect of lameness on daily averages of weekly milk yield, mixed model procedure was applied in the analyses. Lameness incidence of the herd was $9.02 \%$ and most of the lameness events were in the first four weeks. Daily averages of weekly milk yield had significantly decreased in the diagnosis week and continued at a reduced level until 3 weeks after the diagnosis. Whereas milk yield of healthy cows was 30.57 $\mathrm{kg} / \mathrm{d}$, milk yield in the lameness week, first week, second week and third week were $27.52 \mathrm{~kg} / \mathrm{d}$, $27.83 \mathrm{~kg} / \mathrm{d}, 29.15 \mathrm{~kg} / \mathrm{d}$ and $29.80 \mathrm{~kg} / \mathrm{d}$, respectively. Lame cows produced more milk while they were not lame and after the treatment, compared with healthy cows. The effect of lameness on lactation milk yield was not significant.
\end{abstract}

Lactation, disease effect, Holstein, incidence

Animal diseases still play a major role in modern livestock farming. Lameness ranks third in losses from diseases on dairy farms, following mastitis and fertility problems (Baggott 1982). Lameness has a high incidence and causes welfare problems, beside the financial losses. Some of the financial losses caused by lameness are decrease in milk production, the need for extra work and treatment expenses.

Lameness incidence of dairy herds reported in literature varied between 2.1 and 50\% (Barkema et al. 1994; Coulon et al. 1996; Enting et al. 1997; Green et al. 2002, Hernandez et al. 2002; Harris et al. 1988; McLennan 1988; Rajala-Schultz et al. 1999; Warnick et al. 2001). The large differences between the studies on lameness incidence were explained by difficulties in the diagnosis of lameness (Green et al. 2002) and the large number of factors (trauma, infectious diseases, nutrition etc.) causing lameness (Harris et al. 1988). On the other hand, most of the authors (Barkema et al. 1994; Green et al. 2002; Deluyker et al. 1991; Rowlands and Lucey 1986) reported the important relationship between the milk production level or lactation stage and lameness incidence. Barkema et al. (1994), Green et al. (2002) and Deluyker et al. (1991) reported that high yielding dairy cows had a greater risk of lameness. Rowlands and Lucey (1986) reported that the occurrence of lameness after peak yield was associated with high milk production.

The reports on the effect of lameness on milk yield varied in literature. Warnick et al. (2001) reported that lame cows had similar milk production to unaffected herd-mates before the diagnosis of lameness, and after the diagnosis, weekly average milk production of lame cows was significantly lower than that of the unaffected ones. In that study, decrease in milk production accompanying lameness was larger for cows in second or higher lactations than for those in first lactation. Rajala-Schultz et al. (1999) reported that lameness had a negative effect on milk yield, and this effect was significant in Parity 1 and 4 . In their study,

Address for correspondence:

Dr. Omur KOCAK

Istanbul University, Faculty of Veterinary Medicine,

Department of Animal Breeding and Husbandry,

34320 Avcilar, Istanbul, TURKEY
Phone: $0.212 .4737070-17334$

Fax: 0.212.473 7241

E-mail: okocak@istanbul.edu.tr

http://www.vfu.cz/acta-vet/actavet.htm 
the milk-reducing effect of lameness in Parity 1 and 4 began two weeks before the diagnosis and continued for six weeks after the diagnosis. Green et al. (2002) reported that lame cows produced more milk throughout lactation than cows that were never lame. However, Rowlands and Lucey (1986) and Cobo-Abreu et al. (1979) reported that the effect of lameness on 305-d lactation milk production was not significant.

The objectives of the current study were to investigate lameness incidence in a private dairy herd and the effects of lameness on the weekly milk yield and lactation milk yield.

\section{Materials and Methods}

This study was conducted on a private farm in Turkey. The cows were housed in semi-open free-stall barns and were milked three times daily in a milking parlour. As the weather is very hot during summer time, sprinklers and ventilators are used at the farm during the hot hours of the day. The farm has a capacity of 1000 dairy cows and the movement of the cows, production status and the visits of veterinarians are controlled by a computerized herd management program. In the milking parlour a carousel milking system for 50 cows is used. The data on milk yield were transferred to the computer automatically using Afimilk Meters (S.A.E. Afikim, Israel) and the data on diagnosis and treatment practices were transferred to the computer manually.

A ration containing $17 \%$ crude protein and $139 \mathrm{MJ}$ NEL is used for the nutrition of the cows. In the ration, silage (corn and wheat) and hay (barley and wheat) were used as roughage, corn, barley, wheat, wheat bran, soy bean meal and molasses were given as concentrates and feedstuffs such as vitamins and salt were also added.

The animal material of this study was composed of Holstein cows, which were milked between the years 2000 and 2003. A total of 1299 lactation data from 976 cows were collected in this period. Only cows with no diseases and cows with lameness were included in the analyses. Data on the lactation milk yield of cows, recorded over less than 285 days were excluded from the study. Finally, the edited dataset used for analyses comprised 953 lactation data from 787 Holstein cows.

The traits analysed were daily averages of weekly milk yields (DMY) and lactation milk yield (LMY). In the study, lactation milk yield was taken for 44 weeks. While calculating DMY of a cow, her weekly milk production was divided by seven. In the calculation of LMY of cows milked between 285 and 305 days, linear interpolation was applied to estimate the 305-d lactation milk yield. On the other hand, when lactation extended 305 days, only 305 days milk yield was used in the analyses.

The cows were observed for lameness by the workers particularly during care and feeding and when being taken to the milking parlour, and also by veterinarians during their daily controls. Those cows that were observed to have a problem were then inspected in detail by the farm veterinarians and the diagnosis was made. All problems related to hoofs, soft tissue and articulations were recorded as lameness. Lameness was treated by the farm veterinarians according to the structure of lameness.

The first lameness records of the cows that received lameness treatment more than once were taken into consideration. In the study, milk production weeks were separated into ten categories according to the periods in which lameness was observed. These categories were:

1. Cows that never had lameness (healthy cows); and the period until $\geq 3$ weeks before lameness was observed ${ }^{1}$,

2. The third week ${ }^{2}$, second week ${ }^{3}$ and first week ${ }^{4}$ before the diagnosis of lameness,

3. The week in which the diagnosis of lameness was made ${ }^{5}$,

4. First week ${ }^{6}$, second week ${ }^{7}$, third week ${ }^{8}$ and fourth week ${ }^{9}$ after the diagnosis of lameness,

5. $\geq 5$ weeks after the diagnosis of lameness ${ }^{10}$.

To compare lameness incidences for parity groups and lactation weeks, chi-square tests were used. Mixed model procedures were used to analyse DMY. In the analyses of DMY, the following model was used:

$\mathrm{DMY}_{\mathrm{ijklm}}=\alpha+\operatorname{cow}_{\mathrm{i}}+$ parity $_{\mathrm{j}}+$ week $_{\mathrm{k}}+$ lame $_{1}+\mathrm{month}_{\mathrm{m}}+($ parity x week $) \mathrm{jk}+\epsilon_{\mathrm{ijklm}}$ where DMY is the 7$\mathrm{d}$ average of total daily milk production $(\mathrm{kg} / \mathrm{d})$,

$\alpha=$ intercept,

$\mathrm{cow}_{\mathrm{i}}=$ random effect of cow i $(\mathrm{i}=1,2, \ldots 787)$,

parity $_{\mathrm{j}}=$ lactation number $(\mathrm{j}=1,2,3)$,

week $_{\mathrm{k}}=$ lactation week $(\mathrm{k}=1,2, \ldots 44)$,

lame $_{1}=$ lameness category $(1,2, \ldots 10)$

month $_{\mathrm{m}}=$ month in milk $(1,2, \ldots 12)$

(parity $\mathrm{x}$ week $)_{\mathrm{jk}}=$ interaction between parity and week,

$\epsilon_{\mathrm{ijklm}}=$ random residual.

All the terms except cowi and $\in$ ijklm were included in the model as the fixed effect.

To compare DMY of lame cows before the diagnosis of lameness with DMY of healthy cows, the dataset was analysed again. The mixed model used for this purpose included the fixed effects of parity, lactation week, month in milk, lameness stage (lame, healthy) and random effect of cow.

To compare the LMY of lame cows and healthy cows for Parity 1,2 and 3, independent samples $t$-test was applied to separately for Parity 1,2 and 3. To compare LMY of lame cows and healthy cows for the entire dataset, least-squares analysis, which included the fixed effects of parity $(1,2,3)$ and lameness stage (lame, 
healthy) and the random effect of cow was used. SPSS 11.5 (2004) program package was used for the statistical analysis.

\section{Results and Discussion}

Incidences of lameness by parity and lactation weeks are presented in Tables 1 and 2, respectively. The effect of parity on lameness incidence was not significant $(p>0.05)$.

Table 1. Incidence of lameness by parity

\begin{tabular}{|c|c|c|c|}
\hline Parity No. & Number of cows & Number of lame cows & Incidence (\%) \\
\hline 1 & 614 & 48 & 7.82 \\
2 & 247 & 28 & 11.34 \\
3 & 92 & 10 & 10.87 \\
\hline All & 953 & 86 & 9.02 \\
\hline
\end{tabular}

Lameness incidence of the herd (9.02\%) was higher than the results of McLennan (1988) and Rajala-Schultz et al. (1999), similar to the results of Green et al. (2002) and Harris et al. (1988) and lower than the results of some other researchers (B arkema et al. 1994; Coulon et al. 1996; Enting et al. 1997; Hernandez et al. 2002; Warnick et al. 2001; Rowlands and Lucey 1986). Parity 1 had a lower incidence of lameness (7.82\%) compared with Parity $2(11.34 \%)$ and Parity $3(10.87 \%)$, but differences among parity groups were not significant $(p>0.05)$. Similar to our study, Barkema et al. (1994) and Warnick et al. (2001) reported that older cows had a higher incidence of lameness compared with younger cows, but their estimates were significant.

The effect of lactation week on lameness incidence was significant $(p<0.05)$. Most of the lameness events were in the first four weeks and secondly in the period of $5-8$ weeks. $54.65 \%$ of the lameness events were in these two periods.

Table 2. Incidence of lameness by lactation weeks

\begin{tabular}{|c|c|c|c|}
\hline Weeks of lactation & No. of lame cows & \multicolumn{2}{|c|}{ Percentage of lameness (\%) } \\
\cline { 2 - 4 } & & Within all cows & Within lame cows \\
\hline $1-4$ & 31 & $3.25^{\mathrm{c}}$ & $36.05^{\mathrm{c}}$ \\
$5-8$ & 16 & $1.68^{\mathrm{b}}$ & $18.60^{\mathrm{b}}$ \\
$9-12$ & 3 & $0.31^{\mathrm{a}}$ & $3.49^{\mathrm{a}}$ \\
$13-16$ & 3 & $0.31^{\mathrm{a}}$ & $3.49^{\mathrm{a}}$ \\
$17-20$ & 7 & $0.73^{\mathrm{ab}}$ & $8.14^{\mathrm{a}}$ \\
$21-24$ & 7 & $0.73^{\mathrm{ab}}$ & $8.14^{\mathrm{a}}$ \\
$25-28$ & 2 & $0.21^{\mathrm{a}}$ & $2.33^{\mathrm{a}}$ \\
$29-32$ & 5 & $0.52^{\mathrm{a}}$ & $5.81^{\mathrm{a}}$ \\
$33-36$ & 2 & $0.21^{\mathrm{a}}$ & $2.33^{\mathrm{a}}$ \\
$37-40$ & 3 & $0.31^{\mathrm{a}}$ & $3.49^{\mathrm{a}}$ \\
$41-44$ & 7 & $0.73^{\mathrm{ab}}$ & $8.14^{\mathrm{a}}$ \\
\hline Total & 86 & 9.02 & 100.00 \\
\hline
\end{tabular}

$\mathrm{a}, \mathrm{b}, \mathrm{c}: p<0.05$

The incidence of lameness in the initial parts of lactation was higher than other parts, and this result was in agreement with the reports of Barkema et al. (1994), Green et al. (2002) Warnick et al. (2001) and Rowlands and Lucey (1986). Barkema et al. (1994), Deluyker et al. (1991) and Rowlands and Lucey (1986) explained the rise in lameness incidence in the initial stages of lactation by a positive relationship between high milk yield 
and lameness, and they reported that lameness risk might increase with the rise in milk yield.

The least-squares means of DMY by lameness category are presented in Table 3 . The effect of a week of lameness on DMY was significant $(p<0.001)$. There was a significant decrease in milk yield in the diagnosis week and during three weeks after the diagnosis.

Table 3. Least-squares means (LSM) of the weekly average milk productions of dairy cows by lameness category $(\mathrm{kg})$

\begin{tabular}{|c|c|c|}
\hline Lameness category & LSM & SE \\
\hline$\geq 3$ wk before and healthy cows & $30.57^{\mathrm{b}}$ & 0.036 \\
3 wk before & $31.69^{\mathrm{a}}$ & 0.414 \\
2 wk before & $31.07^{\mathrm{ab}}$ & 0.402 \\
1 wk before & $31.02^{\mathrm{ab}}$ & 0.374 \\
Diagnosis week & $27.52^{\mathrm{e}}$ & 0.356 \\
1 wk after & $27.83^{\mathrm{e}}$ & 0.358 \\
2 wk after & $29.15^{\mathrm{d}}$ & 0.360 \\
3 wk after & $29.80^{\mathrm{cd}}$ & 0.365 \\
4 wk after & $30.42^{\mathrm{bc}}$ & 0.372 \\
$\geq 5$ wk after & $31.74^{\mathrm{a}}$ & 0.126 \\
\hline
\end{tabular}

$\mathrm{a}, \mathrm{b}, \mathrm{c}, \mathrm{d}, \mathrm{e}: p<0.001$

DMY of lame cows in the pre-diagnosis period was compared with DMY of healthy cows; and the result of this comparison is given in Table 4. As presented in Table 4, lame cows had more DMY than healthy cows before the diagnosis of lameness $(p<0.05)$.

Table 4. LSM of the daily averages of weekly milk yields (DMY) for lame cows in the pre-diagnosis period and healthy cows $(\mathrm{kg})$

\begin{tabular}{|c|c|c|c|}
\hline & $\mathrm{n}$ & LSM & SE \\
\hline Healthy Cows & 867 & $30.57^{\mathrm{b}}$ & 0.040 \\
\hline Lameness & 86 & $31.41^{\mathrm{a}}$ & 0.169 \\
\hline
\end{tabular}

$\mathrm{a}, \mathrm{b}: p<0.05$

Rajala-Schultz et al. (1999) and Warnick et al. (2001) also reported that the weekly average milk production of lame cows during lameness was significantly lower than that of their unaffected herd-mates. On the other hand, in the present study DMY of lame cows 3 weeks before the diagnosis and 5 weeks after diagnosis was higher than that of healthy cows (the results on the cows $\geq 3 \mathrm{wk}$ before diagnosis are ranked among healthy cows). This result might be explained by the fact that higher milk-yielding cows are at risk of lameness. Therefore their milk yields 3 weeks before the diagnosis and after the treatment, when they were healthy or treated, were higher than healthy cows. To investigate this in more detail, DMY of lame cows before the diagnosis of lameness was compared with DMY of healthy cows (Table 4), and DMY of lame cows in the pre-diagnosis period was found to be higher than DMY of healthy cows $(p<0.05)$. Similarly to our study, Barkema et al. (1994), Green et al. (2002), Deluyker et al. (1991) and Rowlands and Lucey (1986) also reported that high yielding dairy cows were at greater risk of lameness and lame cows produced more milk while they were not lame and after the treatment.

Lactation milk yields of lame and healthy cows by parity are presented in Table 5 . Differences between parity groups were not significant $(p>0.05)$; yet, LMY of lame cows was lower than that of healthy cows for first parity, whereas LMY of lame cows was higher than that of healthy cows for second and third parity. 
Table 5. Lactation milk yields (LMY) of lame and healthy cows by parity (kg)

\begin{tabular}{|c|c|c|c|c|c|c|}
\hline \multirow{2}{*}{ Parity } & \multicolumn{3}{|c|}{ Healthy Cows } & \multicolumn{3}{c|}{ Lame Cows } \\
\cline { 2 - 7 } & $\mathrm{n}$ & LMY & SE & $\mathrm{n}$ & LMY & SE \\
\hline 1 & 566 & 8130.7 & 53.43 & 48 & 7914.4 & 183.48 \\
2 & 219 & 9538.0 & 97.36 & 28 & 9886.2 & 272.27 \\
3 & 82 & 10235.3 & 151.16 & 10 & 10562.0 & 432.87 \\
\hline All & 867 & 9376.7 & 57.56 & 86 & 9626.8 & 189.91 \\
\hline
\end{tabular}

The effect of lameness on lactation milk yield was not significant $(p>0.05)$. This result was similar to the findings of some researchers (Rowlands and Lucey 1986; CoboA breu et al. 1979), but different from those of the study by Warnick et al. (2001) reporting that the loss caused by lameness on lactation milk yield was significant. On the other hand, Green et al. (2002) reported that lame cows produced more milk throughout lactation than cows that were never lame. Whereas the effect of lameness on DMY was significant, the non-significant effect of lameness on LMY might be explained by the following: high yielding cows were at risk of lameness; and therefore in place of reduced milk yield during lameness, their milk yield was higher than that of their herd-mates before lameness and after the treatment.

In conclusion, cows with higher milk production were at risk of lameness. Lameness caused significant milk loss during the disease period, particularly in the diagnosis week and $1 \mathrm{wk}$ after the diagnosis. However, the effects of lameness on the 305-d lactation milk yield were not significant. Hence, the decision of culling for lameness is especially problematic. If lameness is used as a culling criterion, high yielding cows might be culled. On the other hand, preventive applications against lameness and extra management care are needed for high yielding cows.

\section{Vliv kulhání na mléčnou užitkovost dojnic}

Byla sledována incidence onemocnení laminitis u soukromého stáda dojnic a její vliv na týdenní produkci mléka a celkovou produkci za laktaci u dojnic. Data použitá k analýze srovnávala 953 laktací 787 holštýnských dojnic. Analyzované znaky byly denní průměry týdenní mléčné užitkovosti a celková produkce za laktaci. Vliv laminitis na denní průměr týdenní mléčné užitkovosti byl analyzován pomocí protokolu „mixed model procedure“. Incidence laminitis ve stádě byla $9,02 \%$ a většina případů se vyskytla v prvních čtyřech týdnech. Denní průměrná týdenní mléčná užitkovost signifikantně klesla v týdnu, kdy byla stanovena diagnóza a na snížené úrovni setrvala 3 týdny poté. Zatímco mléčná produkce zdravých dojnic byla $30,57 \mathrm{~kg} / \mathrm{d}$, u kulhajících krav byla v týdnu stanovení diagnózy, 1. 2. a 3. týden poté $27,52 \mathrm{~kg} / \mathrm{d}, 27,83 \mathrm{~kg} / \mathrm{d}, 29,15 \mathrm{~kg} / \mathrm{d}$ a $29,80 \mathrm{~kg} / \mathrm{d}$. V době, $\mathrm{kdy}$ dojnice nebyly nemocné a v období po terapii, dojily krávy trpící laminitis ve srovnání se zdravými kravami více mléka. Vliv onemocnění na celkovou produkci mléka za laktaci nebyl signifikantní.

\section{Acknowledgements}

This work was supported by the Research Fund of Istanbul University, Project number: 195/29042004.

\section{References}

BAGGOTT DG 1982: Losses due to lameness caused by physical contact with buildings. Technical Journal 30:12-15

BARKEMA HW, WESTRIK JD, VAN KEULEN KAS, SCHUKKEN YH, BRAND A 1994: The effects of lameness on reproduction performance, milk production and culling in Dutch dairy farms. Prev Vet Med 20: 249-259

COBO-ABREU R, MARTIN SW, WILLOUGHBY RA, STONE JB 1979: The association between disease, production and culling in a university dairy herd. Can Vet J 20: 191-195 
COULON JB, LESCOURRET F, FONTY A 1996: Effect of foot lesions on milk production by dairy cows. J Dairy Sci 79: 44-49

DELUYKER HA, GAY JM, WEAVER LD, AZARI SA 1991: Change of milk yield with clinical diseases for a high producing dairy herd. J Dairy Sci 74: 436-445

ENTING H, KOOIJ D, DIJKHUIZEN AA, HUIRNE RBM, NOORDHUIZEN-STASSEN EN 1997: Economic losses due to clinical lameness in dairy cattle. Livest Prod Sci 49: 259-267

GREEN LE, HEDGES VJ, SCHUNKEN YH, BLOWEY RW, PACKINGTON AJ 2002: The impact of clinical lameness on milk yield of dairy cows. J Dairy Sci 85: 2250-2256

HARRIS DJ, HIBBURT CD, ANDERSON GA, YOUNIS PJ, FITSPATRICK DH, DUNN AC, PARSONS IW, MCBEATH NR 1988: The incidence, cost and factors associated with foot lameness in dairy cattle in southwestern Victoria. Aus Vet J 65: 171-176

HERNANDEZ J, SHEARER JK, WEBB DW 2002: Effect of lameness on milk yield in dairy cows. J Am Vet Med Assoc 220: 640-644

MCLENNAN MW 1988: Incidence of lameness requiring veterinary treatment in dairy cattle in Queensland. Aus Vet J 65: 144-147

RAJALA-SCHULTZ PJ, GRÖHN YT, MCCULLOCH CE 1999: Effects of milk fever, ketosis, and lameness on milk yield in dairy cows. J Dairy Sci 82: 288-294

ROWLANDS GJ, LUCEY S 1986: Changes in milk yield in dairy cows associated with metabolic and reproductive disease and lameness. Prev Vet Med 4: 205-221

SPSS 2004: SPSS for windows advanced statistics release 11.5.

WARNICK LD, JANSSEN D, GUARD CL, GRÖHN YT 2001: Effect of lameness on milk production in dairy cows. J Dairy Sci 84: 1988-1997 